\title{
De foetus verdient meer
}

Citation for published version (APA):

Nijhuis, J. G. (2000). De foetus verdient meer. Maastricht University. https://doi.org/10.26481/spe.20000622jn

Document status and date:

Published: 22/06/2000

DOI:

10.26481/spe.20000622jn

Document Version:

Publisher's PDF, also known as Version of record

\section{Please check the document version of this publication:}

- A submitted manuscript is the version of the article upon submission and before peer-review. There can be important differences between the submitted version and the official published version of record.

People interested in the research are advised to contact the author for the final version of the publication, or visit the DOI to the publisher's website.

- The final author version and the galley proof are versions of the publication after peer review.

- The final published version features the final layout of the paper including the volume, issue and page numbers.

Link to publication

\footnotetext{
General rights rights.

- You may freely distribute the URL identifying the publication in the public portal. please follow below link for the End User Agreement:

www.umlib.nl/taverne-license

Take down policy

If you believe that this document breaches copyright please contact us at:

repository@maastrichtuniversity.nl

providing details and we will investigate your claim.
}

Copyright and moral rights for the publications made accessible in the public portal are retained by the authors and/or other copyright owners and it is a condition of accessing publications that users recognise and abide by the legal requirements associated with these

- Users may download and print one copy of any publication from the public portal for the purpose of private study or research.

- You may not further distribute the material or use it for any profit-making activity or commercial gain

If the publication is distributed under the terms of Article $25 \mathrm{fa}$ of the Dutch Copyright Act, indicated by the "Taverne" license above, 


\section{De foetus verdient meer}

inaugurele rede

J.G. Nijhuis 
(C) JG Nijhuis, Maastricht 2000

ISBN 90-5681-076-6

Vormgeving en druk: Unigraphic, Universiteit Maastricht 


\title{
De foetus verdient meer
}

\author{
Rede \\ uitgesproken bij de aanvaarding van het ambt van \\ hoogleraar obstetrie \\ in de Faculteit der Geneeskunde van de Universiteit Maastricht \\ op donderdag 22 juni 2000 \\ door
}

Dr. J.G. Nijhuis 
"for every complex problem, there is a simple, easy to understand, incorrect answer"

Szent-Gyorgi

De dia's die ten tijde van de oratie werden gepresenteerd staan op internet: http://home.wanadoo.nl/oratie/ 
Mijnheer de rector magnificus,

\author{
Dames en Heren,
}

Vandaag wil ik met $U$ een aantal aspecten van de wondere wereld van de moderne Nederlandse verloskunde bespreken. Verloskunde die zich onderscheidt van de verloskunde in de rest van de Westerse wereld doordat er drie niveaus van begeleiding zijn. De eerste lijn wordt gevormd door de verlos" kundigen en verloskundig actieve huisartsen, de tweede door de vrouwenartsen in niet-academische ziekenhuizen en de derde lijn door gespecialiseerde vrouwenartsen, of liever perinatologen, werkzaam in de academische ziekenhuizen. Nadat ik eerst met $U$ kijk naar medische ontwikkelingen die de verloskundige zorg in de komende jaren zullen beinvloeden, wil ik aan het einde van mijn rede nog enkele woorden wijden aan de organisatie van deze zorg.

Per jaar worden wereldwijd ruim 13I miljoen kinderen geboren, 4,2 per seconde. In Nederland worden bijna 200.000 kinderen per jaar geboren en vanaf dat moment, de geboorte dus, gaat er letterlijk en figuurlijk een nieuwe wereld van zorg open. De periode voor de geboorte onttrekt zich echter voor een groot deel aan de medische zorg. Eenieder denkt dat de wereld van de foetus veilig is, en nauwelijks te beïnvloeden. Ook het aantal onderzoekers dat zich richt op het wel en wee van de foetus is, misschien wel daardoor, relatief beperkt. Eén van de redenen daarvoor is dat de foetus zo goed verborgen ligt in de baarmoeder. De foetus geeft geen antwoord op vragen, kan niet, zoals een baby, geobserveerd worden en met bijna alle technieken worden onderzoekswragen slechts indirect beantwoord. Ik wil $U$ demonstreren dat we toch op de goede weg zijn en vorderingen maken als we de foetus maar meer gaan zien als een zich ontwikkelend mens met een heel eigen ontwikkelingspatroon. Een ontwikkelingspatroon dat na de geboorte wordt voortgezet door de pasgeborene waarbij de geboorte op zichzelf nauwelijks 
betekenis heeft, en een patroon dat ook voor de volwassene niet zonder gevolgen is. Met andere woorden "de foetus is ook maar een mens". Met $U$ wil ik de lijn terug volgen: we starten bij de volwassene, gaan daarna naar de pasgeborene en dan naar het hart van de zaak, namelijk de foetus, om vervolgens in het preconceptionele tijdperk te eindigen.

\section{De volwassene}

Bij volwassenen is al veel onderzoek gedaan naar bijvoorbeeld hart- en vaatziekten. Veel oorzakelijke factoren zijn daarvoor genoemd, andere staan ter díscussie. Pas in de afgelopen jaren wordt steeds duidelijker een verband gelegd tussen chronische ziekten bij volwassenen en de foetale periode. Het is vooral de groep van Barker in Southampton die aandacht heeft gevraagd voor dit fenomeen, dat nu de "Barkerhypothese" of de "fetal origins hypothesis" wordt genoemd. Onder meer diabetes mellitus en coronaire hartziekten komen vaker voor bij mensen die geboren werden met een te laag geboortegewicht. Dit geboortegewicht is weer afhankelijk van de kwaliteit en de kwantiteit van de voeding die de moeder krijgt, en uiteraard van de kwaliteit van de placenta. In een niet-optimale situatie moet de foetus zich aanpassen waardoor orgaansystemen definitief anders gaan werken, met als gevolg dat het risico op aandoeningen in het latere leven groter wordt. Szent-Gyorgi zegt over verklaringen dat "voor elk moeilijk probleem een antwoord bestaat dat simpel is, eenvoudig te begrijpen en niet correct". Mogelijk geldt dat ook voor onze ideeën omtrent chronische ziekten. De foetus verdient vanuit deze visie beslist meer aandacht. Naarmate wij de foetale ontwikkeling beter begrijpen en in staat zullen zijn de intra-uteriene condities te beinvloeden, zal verwacht mogen worden dat de incidentie van chronische ziekten bij volwassenen afneemt. Onderzoeksgelden gaan momenteel grotendeels naar ziekten bij volwassenen. Ombuiging van deze geldstromen naar het begin van het leven zal op zichzelf veelal besparend werken, terwijl als resultante ook de wolwassene gezonder wordt en dus goedkoper. 


\section{Het kind en de pasgeborene}

Ook veel afwijkingen bij kinderen worden beter begrepen als ze bekeken worden door de bril van een kinderarts met kennis van de foetale ontwikkeling. Nog altijd worden kinderen met handicaps geboren en nog altijd ontwikkelen zich handicaps in de loop van de linderleeftijd. Van elke duizend kinderen die geboren wordt, zullen er drie het beeld ontwilkkelen van een "cerebral palsy", een beeld dat gepaard.kan gaan met spasticiteit, mentale retardatie of beide. Werd vroeger met name gedacht dat deze afwijkingen hun oorsprong vonden in een moeilijke geboorte of zuurstofgebrek bij de geboorte, onderzoek van onder meer Nelson en Ellenberg heeft duidelijk gemaakt dat het merendeel van deze handicaps veroorzaakt wordt door gebeurtenissen veel eerder in de zwangerschap.

Voortdurend te veel contracties en herhaald vaginaal bloedverlies zijn voorbeelden van risicofactoren die hiermee geassocieerd worden. Het mag duidelijk zijn welk leed handicaps met zich meebrengen. Meer onderzoek dat tot inzicht in de risicofactoren leidt, gevolgd door reductie van de oorzaken zal kunnen leiden tot een afname van deze aandoeningen. Uiteraard zal $\mathrm{U}$ ook de maatschappelijke relevantie niet ontgaan van onderzoek dat leidt tot een vermindering van het aantal kinderen dat geboren wordt met een handicap. Overigens vroeg Visser in zijn oratie in Utrecht in 1992 ook al aandacht voor dit probleem.

\section{De geboorte}

Natuurlijk betekent dit niet dat de geboorte niet tot schade kan leiden, maar van alle handicaps lijkt slechts Io-15\% door de geboorte veroorzaakt te worden. En misschien ligt een moeilijke geboorte wel besloten in het kind. Dat bedoelde Freud toen hij in 1897 schreef: "difficult birth in itself in certain cases is merely a symptom of deeper effects that influenced the development of the fetus". Is de zwangerschap een periode die je niet van minuut tot minuut en van dag tot dag kunt bewaken, voor de bevalling ligt dat anders. Nu is goede foetale bewaking mogelijk. Soms gebeurt dit nog met een houten toeter, de monauriculaire stethoscoop, waarmee alleen de arts of de verloskundige de harttonen kan horen. Eerder heb ik al betoogd dat dit als een obsoleet instrument moet worden beschouwd. Het gebruik van een 
Doptone maakt de situatie al beter, de ouders kunnen nu in leder geval zelf de harttonen mee beluisteren. In de moderne ze en ze lijns verloskunde wordt het CTG apparaat gebruikt om de foetale hartactie te registreren. Het door deze machine geregistreerde patroon, het cardiotocogram of CTG, wordt vervolgens beoordeeld door de vrouwenarts. In de thuissituatie kan deze machine niet gebruilkt worden, behoudens in sommige thuiszorgprojecten. $U$ dient zich te realiseren dat het CTG het hart is van wat wij de foetale bewaking noemen, terwijl wij ons onvoldoende realiseren dat wij slechts de polsfrequentie registreren. U ziet hier hoe doctor Doubledose de hartfrequentie beoordeelde, met weinig aandacht voor de pols en veel aandacht voor vrouwelijk schoon. Jan Steen schilderde in de r7e eeuw de dokter die met veel meer zorg de pols voelt en $U$ kunt zich voorstellen dat deze dokter al heel wat meer uit de polsfrequentie haalt. De kwaliteit van een diagnostische methode neemt toe met de aandacht die eraan besteed wordt. Dat wij in de verloskunde met name waren op aspecten van de foetale hartfrequentie komt omdat we nog zo weinig anders hebben. Zoals gezegd, het kind zit te goed verborgen en is nog weinig toegankelijk. De toevoeging van andere technieken zoals de meting van foetale saturatie staat nog in de kinderschoenen, terwijl een goede bewaking van de foetus cruciaal is om het doel, de geboorte van een baby in goede conditie, te bereiken. Err lijkt een dilemma te zijn tussen de medicalisering die het gevolg is van optimale bewalking en het gevoel dat de bevalling een volstrekt natuurlijk proces is. Neem nu de onderwaterbevalling. In de miljoenen jaren durende evolutie hebben we een uiterst ingenieus systeem ontwikkeld dat een overgang van leven in vruchtwater naar leven in lucht in slechts luttele seconden mogelijk maakt. Het zal $\mathrm{U}$ niet verbazen dat ik uiterst sceptisch sta tegenover de fillosofie, overigens niet door enig degelijk onderzoek onderbouwd, dat het verstandig zou zijn om na de geboorte nog een extra periode onder water door te brengen. De Raad van bestuur hoeft wat dat betreft niet te vrezen: ik zal niet met een plan komen om elke verlosikamer van een klein zwembad te voorzien.

Wel meen ik dat we met volle kracht moeten streven naar methoden en technieken on de incidentie van zuurstofgebrek rondom de geboorte, perinatale asfyxie, tot een minimum te beperken. Asfyxie die in zijn ernstigste vorm 
kan leiden tot perinatale sterfte. Nederland is een ontwikkeld land en toch lijkt Nederland maar matig te scoren als het gaat om reductie van perinatale sterfte. Het is al te eenvoudig om de organisatie van onze verloskundige zorg daarvan de schuld te geven. In onderzoek dat wij met de verloskundige De Reu deden bleek wel dat in $40 \%$ van de onderzochte sterfte het oorzakelijk moment en dus ook de eventuele interventiekans gelegen was op het moment dat de zwangere alleen nog in de eerste lijn werd gezien., Perinatale sterfte is ook moeilijk te vergelijken met andere landen omdat verschillende definities gehanteerd worden. Echter, de sterfte moet verminderd kunnen worden door verbetering van de kwaliteit van zorg. Deze zal zeker verbeteren als de eerste, tweede en derde lijn meer en beter samenwerken. Het samenwerkingsklimaat is in de laatste jaren aanmerkelijk verbeterd en in het Verloskundig Vademecum hebben verloskundigen, huisartsen en vrouwenartsen zich uitgesproken voor een toename van gezamenlijke en geprotocolleerde zorg. Het is van ultiem belang dat de werkers in dit veld onderkennen dat zij slechts één belang hebben, een gemeenschappelijk belang, namelijk de geboorte vam een gezond kind onder optimale condities. Financieel belang en de plaats van de bevalling, thuis of elders, dient hieraan ondergeschikt gemaakt te zijn. Kijkend naar perinatale sterfte is het bedroevend dat wij geen optimale registratie hebben, de cijfers van het CBS geven nog steeds een onderrapportage aan, en wij hebben ook geen inzicht in de oorzaken van sterfte. De verschillende beroepsgroepen moeten de plicht voelen om alle gevallen wan sterfte te melden en te analyseren. Dit noemen we de perinatal audit. In het Verloskundig Vademecum hebben we aangegeven hoe een dergelijke organisatie er uit zou kunnen zien. Het spreekt vanzelf dat de analyse van een zorgvuldig uitgevoerde perinatal audit inzicht zal geven in risicofactoren in het algemeen, marar wellicht ook zal leiden tot herkenning van risicofactoren die samenhangen met de organisatie van zorg in Nederland. Pas als deze risicofactoren bekend zijn, kan een beleid geformuleerd worden dat gericht is op reductie van perinatale sterfte. Daartoe hoort ook de optimale zorg tijdens de zwangerschap, waarbij op meer gelet kan en moet worden dan op het achterblijven van groei van de baarmoeder en op een eventuele stijgende bloeddruk bij de moeder. Samen met vroegtijdige onderkenning van problemen 
kan gewerkt worden aan evalluatie van mogelijke behandelingsprotocollen. Nog steeds menen veel verloskundigen en vrouwenartsen "gouden handen" te hebben, en ik wil het belang daarvan niet onderschatten.

$1 \mathrm{k}$ denk wel dat een verstandig gebruik van technieken in de komende decennia noodzakelijk is en zal leiden tot een verkleining van genoemde problematiek zonder te veel en onnodige medicalisering.

\section{Zwangerschap}

Een van de belangrijkste vragen in de zwangerschap is: "hoe gaat het met de foetus, hoe is het gesteld met de foetale conditie". Ik heb $\mathrm{U}$ al gezegd dat we de magische polstellerij nog maar marginaal in de vingers hebben. Echoscople helpt ons inzicht te krijgen in structuren en groei. Wat we echt willen is natuurlijk inzicht in de zich ontwikkelende hersenen, in de foetale ontwikkelingsneurologie. I $\mathrm{k}$ ben blij dat de Universiteit Maastricht een leerstoel kinderneurologie heeft ingesteld, collega Vles is reeds benoemd, en het is van belang aan te sluiten met functionele ontwikkelingsneurologie van de foetus. Zoals $U$ weet is de beschrijving van het foetale gedrag al onderwerp geweest van mijn promotieonderzoek en heeft dit onderzoek zich in veel plaatsen woortgezet, in Nederland naast Nijmegen en nu dus Maastricht, onder meer in Utrecht en Amsterdam. Zolang de foetus nog intra-uterien is, is de foetus ontoegankelijk en zullen we met observationele technieken het centraal zenuwstelsel moeten beoordelen. Maar dat heeft alleen zin als we de foetus begrijpen, als we weten wat we bij welke zwangerschapsduur van de foetus mogen verwachten. Laat mij dit illustreren aan de hand van een voorbeeld bij een kind. Als trotse ouders spreken over wat hun kind al kan of doet, wordt dit altijd, maar meestal onbewust gerelateerd aan leeftijd. Want globaal weten de ouders en $U$ ook wat je van een kind op een bepaalde leeftijd mag verwachten. $U$ zou verbaasd zijn als een kind van 6 maanden oud kan lopen, nog verbaasder zou U zijn als datzelfde kind op een leeftijd van 3 jaar nog steeds niet kan lopen. En toch gaat het over hetzelfde kind met hetzelfde zenuwstelsel. Bij de foetus is het feitelijk niet anders. Wat je van een foetus mag verwachten hangt af van de leeftijd. Zoals we al eerder vaststelden: "de foetus is ook maar een mens". Uit Japan komt het fraaie gezegde "bij de geboorte is het 
kind reeds éen jaar oud". Een foetus van 14 weken is in staat tot het maken van kwalitatief fraaie bewegingen, maar bij deze leeftijd kan de foetus nog niet lang stilliggen en vertoont nog geen vaste patronen. $\mathrm{Bij}$ de foetus van 36 weken zijn goed ontwikkelde gedragstoestanden herkenbaar, ook wel slaap-waak-toestanden genoemd. Als een baby een uurtje vast slaapt, is de jonge moeder blij dat ze even rust heeft en zal ze alles doen om te voorkomen dat iemand de rust verstoort. Als de à terme foetus drie kwartier in diepe rust is, wordt het geregistreerde hartfrequentiepatroon strak en zal menig ten onrechte verontruste vrouwenarts alle moeite doen om de foetus te wekken.

Vanaf het prilste begin maakt de foetus en zijn centraal zenuwstelsel een ontwikkeling door die gekenmerkt wordt door een min of meer continu proces. Er is sprake van een continuüm van ontwikkeling, waarbij de overgang van prenataal naar postnataal geen opvallende versnelling initieert. Ook de geboorte zelf is maar een relatief onbelangrijke gebeurtenis, althans gezien vanuit een ontwikkelingsneurologisch standpunt. Indien de geboorte op zich laat wachten zal de foetus, net als de pasgeborene, een groter percentage van de tijd wakker zijn, een fenomeen dat dus niet door de geboorte wordt geinitieerd. Pas weken na de geboorte gaat het centraal zenuwstelsel een nieuwe ontwikkelingsfase in en gaat het kind bijvoorbeeld gericht kijken. Eerder al wees Prechtl op het fenomeen dat de foetus relatief te vroeg geboren wordt. De energiebehoefte van de humane foetus met zijn relatief grote brein is mogelijk zo groot dat de zwangere dat niet meer aan kan. Vanuit de evolutie zijn er twee mogelijkheden geweest: maak de moeder groter of verkort de zwangerschapsduur. De natuur heeft gekozen voor verkorting van de zwangerschapsduur: de intelligente moeder is prima in staat te zorgen voor een relatief prematuur kind. Als men kijkt naar de verdere ontwikkeling van het centraal zenuwstelsel vanuit een "gedragsachtergrond" vallt ook op dat de eerste zes weken geen schokkende ontwikkelingen plaats vinden. En dat is begrijpelijk. De pasgeborene moet, juist wanwege de relatieve vroeggeboorte in de eerste weken na de geboorte veel meer letten op andere dan ontwikkelingsneurologische zaken, bijvoorbeeld temperatuurregulatie, resetting van chemoreceptoren in verband met de toegenomen zuurstofspanning, conti- 
nue ademhaling, orale voeding, etc. Pas nadat deze functies optimaal werken heeft de foetus weer tijd en energie om het centraal zenuwstelsel verder te ontwikkelen.

\section{Het intra-uterien neurologisch onderzoek}

Als observatie van de pasgeborene te weinig oplevert, kan neurologisch onderzoek plaatsvinden bij verdenking op een afwijking wan het centraal zenuwstelsel. Om deze reden wordt ook bij de foetus getracht verder te komen door het ontwikkelen van een intra-uterien neurologisch onderzoek. Zo toonden we aan dat een "primitieve reflex", de intercostaal-phrenicus-inhibitie-reflex, al bij de foetus kan worden opgewekt. Dit bewijst dat neurologisch onderzoek bij de foetus mogelijk is. Echter, deze reflex bleelk niet te discrimineren tussen een gezonde foetus en een bedreigdle foetus, en was klinisch daarom nog niet zinvol. Recent zijn we begonnen met het onderzoek naar foetale habituatie. Met behulp van deze techniek kunnen we zien dat de gezonde foetus steeds minder reageert op een herhaald aangeboden prikkel. Indien de test na enige tijd wordt herhaald, reageert de foetus nog steeds minder, wat erop wijst dat de foetus in staat is tot leren en ook een vorm van geheugen heeft. Wij waren in staat om aan te tonen dat dit leereffect afwezig is bij enkele foetussen met een ernstige hersenafwijking. Andere veelbelovende technieken zijn het intra-uterien MRI onderzoek. Zowel spectroscopie als beeldworming zullen ons kunnen helpen, alhoewel het onderzoek nu nog duur en bewerkelijk is. Dierexperimenteel onderzoek in dit veld, zoals we dat in Nijmegen met een groot team hebben opgezet, liet veelbelovende resultaten zien. Hier ziet $U$ een voorbeeld van een schaap dat in de MRI werd geplaatst om de foetale hersenactiviteit te meten. De foetus moet voor dit onderzoek enige tijd stilliggen en dat kan niet zo maar gerealiseerd worden; de invoering van ultrasnelle MRI-technieken zal hierbuj van voordeel zijn.

De visie dat de foetus ook maar een mens is, helpt ook bij het besef dat de intra-uteriene omgeving niet zo veilig is als vaak verondersteld wordt. Natuurlijk is de aard van de ongelukken die in de baarmoeder gebeuren anders dan die na de geboorte, maar dat is ook het geval als men naar het soort ongelukken kijkt dat de peuter krijgt, of een 18 -jarige of een bejaarde. Door dit concept 
te volgen is het eenvoudiger te begrilipen dat een kind in de loop van een zwangerschap hersenschade kan ontwilkkelen ten gevolge van een "intra-uterien accident". Onbegrepen intra-uteriene sterfte kan voor de oudlers aanvaardbaarder zijn indien het wordt uitgelegd als "intra-uteriene wiegendood". Echter, ook hier is een waarschuwing op zijn plaats, net als bij de onderwaterbevalling. Nu de kennis dat de foetus niet zo maar een bewegend ding in utero is, gemeengoed is geworden, ontstaat opnieuw de onbedwingbare drang om zonder enige aanleiding de foetus te bestoken met de meest vreemdsoortige prikkels. Hierbij moet u zich realiseren dat verschillende onderzoekers hebben aangetoond dat geluid van buitenaf niet gedempt wordt, maar versterkt bij de foetus aankomt. Een klein belletje dat rinkelt op de buik van de moeder, zal voor de foetus mogelijk klinken als een continu luidende kerkklok. De foetus vindt dat waarschijnlijk onaangenaam. 'Toch menen veel leveranciers van kleine belletjes dat zij zwangeren moeten adviseren een dergelijk belletje te dragen om het contact met de foetus te verbeteren. Ik betwijfel of de voortdurende hoofdpijn die de foetus mogelijk van dat belletie krijgt, leidt tot een sterkere moederbinding in de toekomst. Anderzijds beginnen we ons ook af te vragen wat de foetus nog meer kan horen of voelen, mogelijk zijn sommige prikkels echt pijnlijk. Pijn en bewustzijn hangen nauw samen en het belangrijke vraagstuk omtrent foetaal bewustzijn krijgt nog te weinig aandacht.

\section{Prenatale diagnostiek}

In de zwangerschap neemt ook prenatale diagnostiek een belangrijke plaats in. Historisch wordt hierbij vooral gedacht aan vruchtwater- en vlokkenonderzoek om chromosomale afwijkingen zoals het Downsyndroom uit te sluiten. Dit onderzoek wordt in Nederland aangeboden indien de zwangere 36 jaar of ouder is, omdat met de toenemende leeftijd van de zwangere het risico op het krijgen van een kind met een chromosomale afwijking toeneemt. Maar meer en meer zijn ook erfelijke ziektem in kaart gebracht en in toenemende mate is prenatale diagnostiek van die ziekten op DNA-niveau mogelijk. Met een voortschrijdend inzicht in het menselijk genoom zullen steeds meer aandoeningen opgespoord kunnen worden. 
Als het gaat om structurele afwijkingen, heeft vooral de invoering van de moderne echoscopie-apparatuur grote invloed gehad op de mogelijkheden wan prenatale diagnostiek. In Nederland is screening van afwilkingen afgewezen en onderzoek wordt alleen bij risicogroepen verricht. Hiertoe behoren niet alleen de oudere zwangeren, maar ook ouders die een kind kregen met een bepaalde afwijking. Tripletest en nekplooimetingen zijn niet-invasieve methoden die hun nut hebben bewezen maar die ook nog niet aan alle zwangeren aangeboden mogen worden. Het valt te werwachten dat in de komende jaren deze vorm van onderzoek een sterke groei zal blijven kennen. Zeker leidt prenatale diagnostiek ook tot uitslagen waarvan het zelfs voor de klinisch geneticus moeilijk is te voorspellen wat dat precies betekent voor de foetus. Denk hierbij aan de aanwezigheid van een (extra) markerchromosoom dat niet eerder in de familie werd gevonden. Wellicht wordt de tijd rijp voor een beperkte vorm van onderzoek, zodat alleen bepaalde aandoeningen worden witgesloten, terwijl men de rest van het chromosomenpatroon onbeoordeeld laat. Ook financieel zou dit gunstiger zijn. Nog nuttiger lijkt het om het gebruik van niet-inwasieve diagnostiek voor een grotere groep te propageren, dus toch screening van alle zwangeren mogelijk te maken. Chromosomale afwijkinged kunnen dan niet met zekerheid worden uitgesloten, maar wel kan bij elke zwangere een persoonlijke risicoschatting worden uitgevoerd. Hierna kan de zwangere bepalen of zij dit risico aanvaardbaar vindt, waarbij dit risico moet worden afgezet tegenover het risico dat ten gevolge van de volgende stap, een vruchtwaterpunctie of vlokkentest, een miskraam optreedt.

Voor veel mensen blijft prenatale diagnostiek een bedreiging vanwege het "hellend vlak" risico" ouders zouden steeds lichtvaardiger beshuiten tot het afbreken van een zwangerschap bij het aanwezig zijn van een bepaalde afwijking. Vele jaren ervaring in dit veld maken dat ik ervan overtuigd ben dat dit risico niet reèel is. I $\mathrm{k}$ ben het dan ook met geheel oneens met de these wan de "proefzwangerschap", die zegt dat je een zwangerschap wel aangaat maar niet echt in verwachting bent totdat de prenatale diagnostiek achter de rug is. Het tegendeel is waar. In alle gevallen van prenatale diagnostiek gaat het om zeer gewenste zwangerschappen die soms met veel 
moeite zijn ontstaan. Als echter een afwijking aanwezig blijkt te zijn, ontstaat het dilemma van een haast onmaakbare keus: de afbreking van de zwangerschap versus het accepteren van de zwangerschap en het kmijgen van een kind met de vastgestelde aandoening. Tot welk besluit de aanstande ouders ook komen, er is geen goed besluit en geen fout besluit, ze hebber altijd levenslang. Levenslang de vraag of het goed was de zwangerschap af te breken versus levenslang de zorg voor een kind met ernstige handicaps. De keus wordt nog klemmender omdat de ouders vaak aangeven dat zij niet voor zichzelf kiezen, maar dat zij hun kind het leven met een handicap niet willen aandoen. Vanuit deze kennis wordt door de meeste centra meer en meer begeleiding geboden bij dit besluitvormingsproces. Centra waarin ouders niet optimaal begeleid kunnen worden om in wolledige vrijheid tot welke keuze dan ook te komen, zouden zich moeten beraden op hun positie. De schrijnende problematiek wordt verergerd in een omgeving die afkeurend reageert op het eventueel afbreken van de zwangerschap of een omgeving die de omvang van het besluit bagatelliseert. $\mathrm{k}$ ben blij in een omgeving te werken waarin de keuze van de vrouw en haar partner voorop staat en de begeleiding optimaal wordt vorm gegeven door een uitstekend werkend prenataal team.

Ook zal meer aandacht besteed moeten worden aan therapeutische mogelijkheden. Tot op heden gaat het hier vooral om intra-uteriene transfusies, terwijl intra-uteriene chirurgie nog steeds geen echte mogelijkheden creëert. Zolang dat niet het geval is en veel afwijkingen vastgesteld worden op een moment dat een zwangerschapsafbreking niet meer aan de orde is, in Nederland is dat na 24 weken, moet maximale energie gestoken worden in de verdere begeleiding. Als wij hier in het azM in nauwe samenwerking met Eindhoven de afdeling prenatale diagnostiek meer vorm willen geven, zal steeds duidelijker gekozen moeten worden voor het uitbouwen van en de samenwerking tussen de verschillende subdisciplines. Zonder de aanwèzig. heid van goede neonatologen, kinderneurologen, kinderchirurgen, kinderne. frologen, kindercardiologen, kinderhartchirurgen, enzovoorts, kan een centrum nauwelijks vorm lorijgen. Immers, ook hier geldt dat het vaststellen van een aandoening gevolgd moet kunnen worden door een goed vervolgtraject en niet door verwijzing naar elders. Uiteraard staat deze uitspraak niet in de 
weg dat bepaalde ziekenhuizen binnen een regio, of in ons geval de Euregio, specifieke expertise kunnen ontwikkelen. Dit zal alleen maar leiden tot een sterke verbetering van de kwaliteit van zorg.

I $\mathrm{k}$ hoop dat we over enkele jaren niet alleen een goed centrum hebben voor prenatale diagnostiek maar ook een centrum voor diagnostiek en therapie woor foetus en pasgeborene. Een dergelijke naamgeving wijst wederom naar het continuüm van zorg en brengt de foetus in een minder geïsoleerde positie.

\section{Conceptie en preconceptie}

We naderen in onze tocht nu de laatste fase, die van conceptie en preconceptie. Nog te weinig realiseert men zich dat de foetus al bijna geheel is aangelegd op het moment dat de zwangerschapstest wordt verricht. Pas dan wordt gestopt met roken, alcoholgebruik of vraagt men zich af of het gebruik van bepaalde medicijnen niet schadelijk is. De gezondheidsraad heeft gelukkig al op schrift gesteld dat elke vrouw die zwanger wil worden preconceptioneel zou moeten starten met het gebruik van foliumzuur. Hierdoor kan de incidentie van een ernstige afwijking, het open ruggetje of het neuraalbuis defect, duidelijk verlaagd worden. Goed onderzoek in de komende jaren zal leiden tot meer inzicht in het ontstaan van verschillende congenitale afwijkingen en mogelijk ook tot inzicht in de preventie ervan. Het aandeel van de geneticus waarmee de perinatoloog zo intensief samenwerkt zal hier van eminent belang blijven. Ook zullen er meer mogelijkheden komen tot het doen van PGD, pre-implantatie genetische diagnostiek, zeker indien de IVF-procedures succesvoller en minder belastend gaan worden. Op deze wijze komt een oplossing in zicht voor het dilemma van een eventuele zwangerschapsafbreking.

Ik verheug mij te werken in een centrum dat nu al naam heeft gemaakt met genoemde methoden. De belangrijkste preventieve mogelijkheden liggen echter voor het grijpen. Huisartsen, internisten, longartsen, diabetologen, neurologen, zij allen die jonge mensen behandelen met aandoeningen die of erfelijk zouden kunnen zijn of zouden kunnen interfereren met optimale reproductie, zouden een actief beleid moeten voeren met betrekking tot het vroegtijdig bespreken van een pre-conceptioneel advies. Deze counseling 
maakt dat bij risicogroepen zwangerschappen kunnen ontstaan onder optimale condities. Dit zal de foetus ten goede komen, en -de Barkerhypothese volgend-zijn gewolgen hebben voor onze zorg in het algemeen.

\section{Verloskundige zorg}

Ik heb U beloofd onze verloskundige zorg nog kort te benoemen. In Nederland begint een zwangere de controles bij de verloskundige in de $\mathrm{I}^{\mathrm{e}}$ lijn. Indien geen risicofactoren aanwezig zijn en de zwangerschap ongecompliceerd verloopt, blijft de verantwoordelijkheid bij de eerste lijn en kan zelfs een thuisbevalling een feit worden. In Nederland bevalt nog geen $50 \%$ van de vrouwen die bij de verloskundige begint ook daadwerkelijk bij de verloskundige, de meerderheid belandt op enig moment bij de vrouwenarts in het ziekenhuis, de tweede lijn, of in het academisch ziekenhuis, de $3^{e}$ lijn. Voor de zwangeren die hun eerste kind krijgen ligt de kans op een bevalling in de $\mathrm{r}^{\mathrm{e}}$ lijn slechts op $35 \%$, dus tweederde wordt verwezen. Dit maakt de verloskunde wel duur want een groot deel van de verloskundige zorg en van de bevallingen wordt nu dubbel gedeclareerd, zowel door de verloskundige als door de vrouwenarts. Die extra kosten worden geraamd op ongeveer 65 miljoen gulden per jaar.

Verder staat of valt ons systeem met goede mogelijkheden van transport naar en van het ziekenhuis. Minister Borst heeft al aangegeven dat wij in Nederland terugmoeten naar maximaal 40-60 beddenhuizen en dit heeft onmiddellijke consequenties. De afstanden tot de grote, gefuseerde ziekenhuizen zullen zodanig worden dat thuis bevallen in delen van het land onverantwoord. wordt. Daarbij komt dat transport, bijvoorbeeld tijdens de bevalling, steeds ingewikkelder en duurder wordt door de steeds toenemen" de verkeersdrukte. Een ander facet is de verloskundige zelf. De verloskundige wil geen werkweken van 80-100 uren meer en gaat ook op zoek naar groepsworming of liever nog naar een ziekenhuisfunctie met normale werkweken. De eerder genoemde samenwerking en protocollering zal bijdragen aan een sterker gevoel van veiligheid indien de eerste lijn ook fysiek kan samenwerken met de tweede lijn. Voor de toekomst betekent dit scenario dat de thuisbevalling verdwijnt, en dat de meerderheid van de verloskundigen in 
dienstverband in ziekenhuizen zullen gaan werken. Protocollering van zorg wordt dan meer vanzelfsprekend en ook een goede perinatal audit kan beter worden gerealiseerd, Nederland zal zich kunnen meten met de resultaten van de omringende moderne landen. Dit alles kan alleen als de eerste lijn qua opleiding in stand blijft. Met andere woorden: de verloskundige wordt opgeleid dóór en vóór de eerste lijn, blijft gericht op een niet-gemedicaliseerde baring en behoudt -ook in ziekenhuizen- een eigen autonomie. Dit zou een heel adequate vorm van verloskundige zorg zijn waarmee Nederland zijn bijzondere verloskundige positie behoudt, ondanks dat de thuisbevalling verdwijnt: Uiteraard betekent dit ook dat de ziekenhuizen hun toekomstplannen voor de verloskundige afdelingen zullen moeten bijstellen.

\section{Onderzoek en onderwijs}

De woorden onderzoek en onderwijs zijn reeds gevallen, en niet toevallig. Bij mijn binnenkomst werd ik tot mijn vreugde onmiddellijk betrokken bij de plannen tot herziening van het curriculum voor studenten geneeskunde. Dat juist mensen met een andere achtergrond mee kunnen denken in deze commissie "blauwdruk" typeert de sfeer van de universiteit van Maastricht. Ik zal met veel genoegen actief blijven in het onderwijs, de basis van de geneeskundige zorg. Zoeken naar een breed draagvlak voor de vorm waarin het onderwijs gegeven wordt, met veel respect voor de student èn de docent staan hierbij voorop.

Ook qua onderzoek liggen meerdere velden open. Zowel richting preconceptionele zorg en prenatale diagnostiek, alsook richting foetaal gedrag en de gevolgen van perinatale asfyxie. Ik heb met veel vreugde vastgesteld dat aandacht hiervoor breed aanwezig is zowel bij onze eigen afdeling, als bij de afdelingen klinische genetica, kindergeneeskunde, kinderneurologie en kinderpsychiatrie. Ik hoop in de komende jaren mee vorm te kunnen geven aan helder opgezette onderzoekslijnen waarin veel disciplines zullen samenwerken, en waarin ieder zichzelf toch kan blijven herkennen. Alleen op die wijze kunnen ook studenten vroegtijdig instromen en aansluiten bij goed georganiseerde onderzoekslijnen, en wordt chaotische versnippering voorkomen. Ik steun van harte de mening van Nieuwenhuijzen Kruseman die bij de afgelopen Dies Natalis opriep om alerter te zijn op de aanwezigheid van 
jong talent en ruimte te creëren on vroegtijdig met onderzoek te kunnen beginnen. Alleen dan kan een wetenschappelijke opleiding zich onderscheiden van een beroepsopleiding.

Ook met veel genoegen heb ik gezien hoe ziekenhuis en faculteit nauw met elkaar samenwerken zonder geheel te integreren, cen goede keus. Dat wij verder moeten werken naar intensieve protocollering is nog niet elke ziekenhuisdirectie duidelijk, maar gelukkig heb ik van Carpay meerdere malen mogen horen hoe hij dat in de komende jaren ziet en onze vakgroep zal hem daarin van harte steunen.

In het licht van de zaken die ik aan de orde gesteld heb moet met nadruk gesteld worden dat realisatie van plannen alleen lan plaatsvinden door intensieve samenwerking, niet alleen tussen de verschillende speciallisten, maar met name ook met de eerste en tweede lijn. Hiermee is reeds begonnen, en door parttime aanstellingen van gynaecologen uit de $2^{\mathrm{e}}$ lijn binnen onze afdeling krijgt deze samenwerking reeds nu gezicht. Ik vertrouw ook op het overleg met de eerste lijn dat al flink structuur heeft gekregen. Zo dient het azM te participeren in de opleiding van verloskundigen, bijvoor* beeld door stages in het academisch ziekenhuis mogelijk te maken. Uiteindelijk zal van elke verbetering in de kwaliteit en de organisatie van zorg de foetus het meest kunnen profiteren, en, dat weet $U$ inmiddels, daar was het allemaal om begonnen.

\section{Conclusie}

\section{Dames en heren,}

Ik hoop dat ik $U$ duidelijk gemaakt heb dat de foetus meer verdient. Misschien geen thuisbevalling meer, maar wel een goede perinatal audit, meer onderzoek preconceptioneel, meer zorg voor prenatale diagnostiek, bij voorkeur niet-invasief, meer onderzoek naar en zorg voor de bewaking van de foetale conditie, meer zorg om wat de foetus hoort en voelt, meer zorg rondom de geboorte, meer onderzoek naar oorzaken van handicaps, en meer onderzoek naar foetale factoren die de kwaliteit van het latere leven kunnen beïnloeden. Dat de maatschappij daar wel bij zal varen is zeker ${ }_{v}$ en dat de foetus dus ook meer geld dient te verdienen, is slechts een logische consequentie. 


\section{Dankwoord}

Nu ik aan het einde van mijn betoog ben gekomen wil ik graag een aantal mensen bedanken, niet omdat de traditie dat wil, maar omdat ik hier niet zou staan zonder de hulp van velen. Zonder mensen te kort te willen doen, zal ik vaker een groep van mensen noemen dan afzonderlijke namen.

Allereerst het College van Bestuur van de Universiteit Maastricht en de Raad van Bestuur van het Academisch Ziekenhuis Maastricht die deze leerstoel instelden. Ook dank aan het faculteitsbestuur en de benoemingscommissie, en aan de hooggeleerde De Haan. Jelte, ik denk dat jij bij de initiatiefnemers hoort. I $\mathrm{k}$ ben voornemens in de komende jaren te laten zien dat Uw keuze een juiste was en ik hoop dat dat vooral zichtbaar zal worden in onderzoekslijnen, kliniek en in het medisch curriculum.

Mijn carrière begon bij de hooggeleerde Folgering. Hans, jij had vanaf het prilste begin vertrouwen in een langharige en controversieel geklede student-assistent die met jou jarenlang de practica medische fysiologie zou gaan verzorgen. Jij leidde mij ook richting wetenschap en de zeergeleerde Bots. Rob, jouw niet aflatend enthousiasme heeft indertijd tot mijn proefschrift en opleiding geleid.

De hooggeleerde Eskes en de zeergeleerde Broeders waren mijn opleiders samen met hun beider maatschappen. Het opleidingsklimaat in Nijmegen en 's-Hertogenbosch was uitstekend geschikt om kliniek en wetenschap te combineren. Mijn promotores waren de hooggeleerden Martin en Prechtl en co-referent Eskes. Het was een enorme eer om met zo'n team te mogen werken: verschillende disciplines en verschillende nationaliteiten. Bart, Heinz en Tom, ik ben jullie veel verschuldigd. Ik acht jullie kwaliteiten uitzonderlijk hoog en ben er zeker van: als jullie waren gaan voetballen was je ook prof geworden.

De hooggeleerde Visser. Gerard, onze paden kruisen zeer frequent. Door de jaren heen heb ik veel van je geleerd, en alles wat we samen deden, deden 
we met veel enthousiasme en ontzettend veel plezier. Ik zeg je dank voor alle steun en vertrouw erop dat wij in goede vriendschap blijven samenwerken.

Van de perinatologen in Nederland wil ik ook de hooggeleerde Bruinse niet ongenoemd laten. Hein, hoeveel uren hebben wij al niet, en met succes, besteed aan allerlei ideeën om perinatologisch Nederland meer vorm te geven. Over jouw hoofd heen wil ik natuurlijk alle perinatologen, en in het bijzonder de "Otterlo-groep", danken voor de samenwerking door de jaren heen.

Veel werk werd verzet binnen de Nederlandse Vereniging voor Obstetrie en Gynaecologie, de NVOG. Het is fantastisch te kunnen werken met een bureau dat zo geprofessionaliseerd is dat het vanmiddag gesloten is, want de dames van het bureau zijn hier! Ik dank de NVOG, het bestuur en de vele commissies voor het vele dat we al gedeeld hebben en ik zal me actief blijven inzetten voor deze belangrijke wetenschappelijke vereniging.

Mijn oude stek, het St. Radboudziekenhuis heb ik verlaten. Ik kijk met weemoed op veel goede jaren terug. Van mijn oude maten wil ik vooral Van Dongen, Dony en Schijf noemen, van mijn jonge maten met name Van den Berg, Boekkooi en Kremer. Ieder van hen heeft op eigen wijze bijgedragen tot wat ik nu ben. En natuurlijk de zeergeleerde Jongsma. Henk, wat hebben we veel onderzoek samen gedaan en begeleid en onze samenwerking is beslist nog niet ten einde. Dank ook aan allen die bijgedragen hebben tot het opzetten van de afdeling prenatale diagnostiek en therapie.

In mijn nieuwe stek, het azM, voelde ik me al snel thuis. Onder het waarnemend hoofdschap van de zeergeleerde Frans Smits is het goed toeven, en ik heb ervaren dat de maatschap mij met vertrouwen heeft binnengehaald. Ook heb ik hier een enthousiaste assistentengroep ontmoet, en ik hoop in de komende jaren mee te kunnen sturen op weg naar een optimaal draaiende kliniek met een fantastische opleiding. Hierbij vertrouw ik op een goede harmonie tussen de divisiehoofden Evers, ondergetekende en een 
nog te benoemen derde hoogleraar. In onze obstetrische divisie wordt de samenwerking met Essed, Hasaart, Offermans, Peeters en Smits al steeds hechter. Ook de samenwerking met de neonatologische staf onder leiding van de hooggeleerde Blanco heeft hoge prioriteit want alleen samen kunnen we de perinatologie vorm geven.

Dan zijn er nog zoveel meer vrienden om me heen. De naam van collega Robert Krakers wil ik noemen omdat ik hem door de jaren heen beschouw als mijn beste vriend, alle anderen spreek ik vandaag persoonlijk nog.

Dan kom ik bij de laatsten maar niet de minsten aan. Op een dag als vandaag weet je dat het gemis wan ouders nooit meer over gaat. Met de wetenschap hoe trots ze zouden zijn geweest zal ik het nu moeten doen. Wat ze hebben achtergelaten is een groot gezin dat nog steeds veel samen optrekt. Een warm gezin waarin de zaak en de discussie voorop stonden. Elk onderwerp kon en kan op elk moment van de dag in discussie gebracht worden, elk argument wordt besproken, geen enkel argument is te wild, zolang de zaak maar openblijft! Misschien leidde deze sfeer tot een flexibiliteit van denken die mogelijk maakte dat drie van de zeven kinderen zich inmiddels hooggeleerd mogen noemen. Na vandaag kijk ik uit naar de oratie van Ton, mijn jongste broertje, op 3 juli in Amsterdam.

Mijn schoonouders, Mineke en Jan Kloen, wil ik noemen. Ik heb nooit eerder echte schoonouders gehad, maar ik denk dat zij er de oorzaak van zijn dat ik de clou van die grappen over schoonouders nooit begrijp.

Dan de kinderen, Tim, Annelijn en Olivier. Het is niet niks als je zo maar naar Maastricht moet verhuizen, laat staan naar Gronsveld. Ik ben trots op jullie, en niet alleen omdat jullie mijn plannen steeds met grote solidariteit hebben gesteund. En volgende week gaan we weer gewoon naar het hockeyveld.

Tenslotte, Marjan, echtgenote en steun en toeverlaat, al weer heel wat jaren. Ik weet dat ik het je niet altijd makkelijk maak, en ik vind het knap dat je, 
zonder jezelf weg te cijferen, mij toch steeds de ruimte geeft die deze carrière nodig heeft. Vandaag kan ik je geen groter compliment maken dan door te zeggen: "de foetus verdient meer, maar jij verdient het meest".

Ik heb gezegd. 


\section{Referenties}

- Barker DIP. Fetul programming and public health Ini (Ed O'Brien PMS, Wheeler T, Barker DJP) Fetal programming; infuences on development and disease in later life. RCOG Press "London, 1999: Pp y-rz.

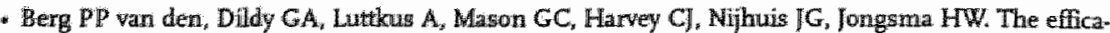
cy of intrapatum fetal sarveillance when fetal pulse oximetry is added to cardiotocotraphy.

Eur l Obstet Gynecol Reprod Biol 1997; 72 (suppl I): S67.57\%.

- Camaichael AO and Ratzan RM. Medicine in literature and art Könemann, Koln, 99 r.

- Cappellen vari Walsum AM wan, Heerschap A, Nihuis JG, Oeseburg B Jongsma HW. Hypoxia, the subsequent systemic metabolic acidosis, and their relationship with cerebral metabolite concentration: An in vivo study in fetal lambs with proton magrietic resonance spectroscopy. Am / Obstet Gynecol 1999; 18in: $1537 \% 1545$.

- Dildy GA, Berg van den PP, Katz M, Clark SL, Jongsma IFW, Niphuis JG, Loucks CA. Intrapartum fetal pulse oximetry: Fetal oxygen saturation trends durimg labor and relation to delivery outcome. Arn ) Obstet Cynecoll r994: 17: $679-684$.

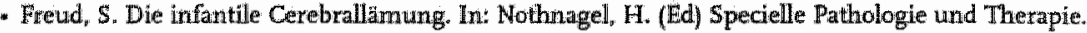

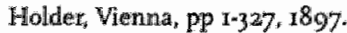

- Hamson MA, Najhuia JG. Pulse oximetry - physiological considerations. Eur / Obstet Gynecol Reprod Biol 1997. 72 (suppl r): $\$ 3.58$.

- Fetal Awareness, report of a working party. The Royal College of Obstetricians and Gyraecologists, RCOG press, London, 1997.

- Holm, I.P. De eerste de beste? Oratie, Rijksuniversilteit Groningen, 1996.

- Nelson, K.B. and Ellerberg, J.H. Intrapartum events and cerebral palsy. In: Kubli et al (Eds) Prenatal

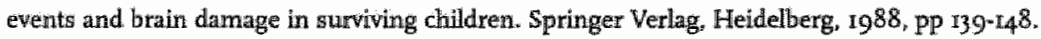

- Nijhuis JG. Behavioural states in the human fetus. Proefschrift Nijmegen, 19,84 .

- Nijhuis JG (ed). Fetal Behaviour: Developmental and Perinatal Aspects. Oxford Medical Publications I992.

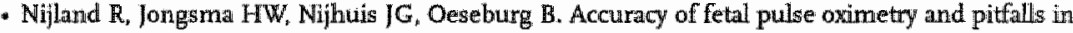
measurements. Eur j Obstet Gynecol Reprod Biol I997* 72 (suppl in): \$21-S27.

- Peters A.J.M. The fetal sound and vibration environment. Transmission and distribution of sound and vibration in the abdominal cavity of sheep. Proefschrift, Utrecht $199 \%$.

- Prechtl HIR. New perspectives in early human development. Europ / Obstet Gynecol Reprod Biology I986" 21: 347-355.

- Rothman B.K. The tentative pregnancy, Viking Press, 1986 .

- Var de Pas M. Nijhuis JG, Jongsma HW. Fetal behaviour in uncomplicated pregnancies after 41 weeks of gestation. Early Human Devi 1994" $40: 29 \% 38$.

- "Tus BAPI, Nifhuis JG. The intercostal-to-phrenic-inhibitory reflex (IPIR) in normal and intra-uterine growth-retarded (UUCR) human fetuses from 26 to 40 weeks of gestation. Early Human

Development 1993: 32: 1777-18:

- Verloskundig Vademecum, Ziekenfondisraad r999. Arnstelveen.

- Visser G.H.A. De sluier van Maya, oratie, rijksuniversiteit Utrecht, 1992.

- Vries JIP de, Visser GHA. The emergence of fetal behaviour. L. Qualitative aspects. Early Humart Dexelopment $198: 27: 301-322$.

- Wegers "TA, Hingstman L, wan der Zee J. Thuisbewalling in gevarar. Medisch Contact, 55; 19: 70rogo. 